\title{
Simultaneous analysis and occurrences of six pharmaceuticals in surface water by LC/ESI-MS/MS
}

\author{
ByungJu Kim and Seung-Woon Myung ${ }^{\star}$ \\ Department of Chemistry, Kyonggi University, Suwon, 443-760, South Korea \\ (Received December 6, 2010; Accepted December 7, 2010)

\section{LC/ESI-MS/MS를 이용한 하천수 중 잔류 6종 의약물질의 동시분석 및 모니터링} \\ 김병주 · 명승운` \\ 경기대학교 화학과 \\ (2010. 12 6. 접수, 2010. 12. 7. 승인)
}

\begin{abstract}
In this study, sample preparation and analytical method for the monitoring of six pharmaceuticals (cephradine, cefadroxil, penicillin G vancomycin, iopromide, and fenbendazole) in surface water was investigated. The extraction/clean-up and concentrating of pharmaceuticals from surface water were performed by HLB (Hydrophilic-Lipophilic Balanced) cartridge. The method allows for the simultaneous determination of six pharmaceuticals by HPLC/ESI(+)-MS/MS. Recoveries of the pharmaceutical were between 71.1 to $92.6 \%$ (except fenbendazole) and the overall variability of the method was below $11.2 \%$ (RSD). The calibration curves for the pharmaceuticals from blank surface water showed good linearities (above $r^{2}=0.99$ ) in the concentration range of $0.007 \sim 1.2 \mathrm{ng} / \mathrm{mL}$. The limit of detection (LOD) and the limit of quantification (LOQ) were 7.2 128.7 $\mathrm{pg} / \mathrm{mL}$ and $23.8 \sim 429.1 \mathrm{pg} / \mathrm{mL}$, respectively. The present analytical method can be useful for monitoring residual pharmaceuticals in surface water and other aquatic samples. High concentrations of iopromide and fenbendazole were detected in a few samples of surface water.
\end{abstract}

요 약: 본 연구에서는 하천수 중 6종의 의약물질(cephradine, cefadroxil, penicillin G vancomycin, iopromide, and fenbendazole)에 대한 전처리법과 분석 방법을 확립하였다. 하천수 중의 분석물질을 HLB(HydrophilicLipophilic Balanced) 카트리지를 사용하여 추출/정제 및 농축하였다. HPLC/ESI-MS/MS를 이용하여 6종 의 물질들을 동시에 분석하였다. Fenbendazole을 제외한 의약물질은 $71.1 \sim 92.6 \%$ 범위의 양호한 회수율을 나타내었고, 상대표준편차는 $11.2 \%$ 이하로 나타났다. 정량분석을 위해서 $0.007 \sim 1.2 \mathrm{ng} / \mathrm{mL}$ 범위에서 $\mathrm{r}^{2}=0.99$ 이상의 높은 직선성을 나타내는 검량선을 얻었다. 검출한계(LOD)와 정 량한계(LOQ)는 각각 $7.2 \sim 128.7 \mathrm{pg} / \mathrm{mL}, 23.8 \sim 429.1 \mathrm{pg} / \mathrm{mL}$ 로 나타났다. 이 분석 방법은 하천수 중 의약품에 대한 모니터링에 유 용하며, 하천수 중 iopromide과 fenbendazole은 높은 농도로 검출되었다.

Key words: pharmaceuticals, surface water, chemical analysis, LC/ESI-MS/MS

Corresponding author

Phone : +82-(0)31-249-9647 Fax : +82-(0)31-249-9647

E-mail : swmyung@kgu.ac.kr 


\section{Introduction}

Recently many kind of antibiotics have been used to treat bacterial diseases in humans and domestic animal, as well as to promote animal growth for economic profit. A high percentage of pharmaceuticals consumed by humans and animals in hospitals or by prescription are excreted unchanged via urine, and feces into domestic sewage and are discharged to wastewater treatment plants (WWTPs). The pharmaceuticals are only partially removed and are released through the effluent of treatment plants into aquatic environments. ${ }^{1-3}$ The pharmaceutical can be given credit for longer life spans of humans and animals, but bacterial resistance to antibiotics has become serious problems encountered in clinical treatment, and the residual existence in the aquatic environment

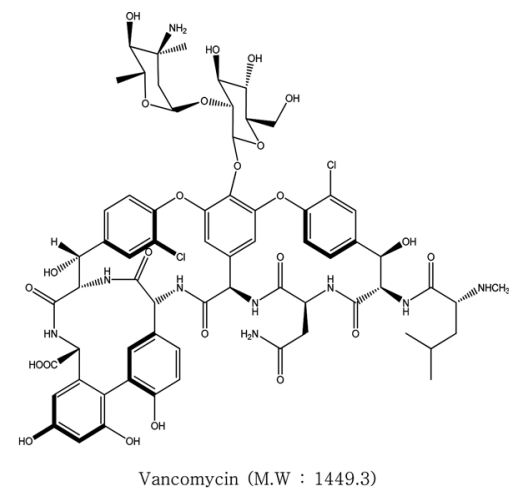

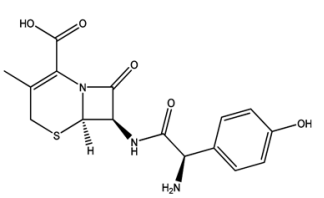

Cefadroxil (M.W : 363.3)
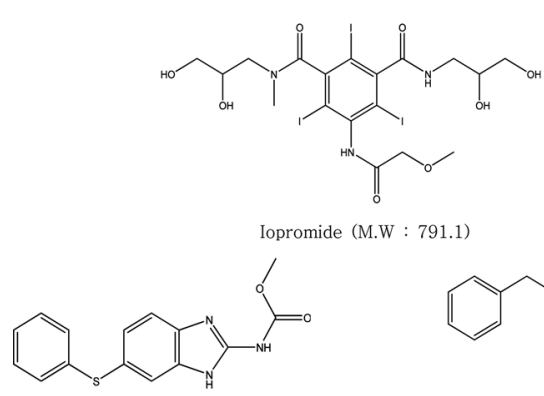

Fenbendazole (M.W : 299.4)

Fig. 1. Chemical structures of the six pharmaceuticals have been linked with the formation of antibiotic resistance. $^{4,5}$

The quantitative analysis of pharmaceuticals in an aqueous environment is difficult because of the fact that pharmaceuticals exist in low concentration levels ( $\mathrm{pg} / \mathrm{mL} \sim \mathrm{ng} / \mathrm{mL}$ ) and the matrices are complicated and what's more, physico-chemical properties of pharmaceuticals are diverse. ${ }^{6,7}$ Consequently, a highly sensitive and selective analytical method are needed to monitor pharmaceuticals in an aqueous environment. $^{8-10}$

LC/MS and LC/MS/MS were used in the analysis of six pharmaceuticals (cephradine, cefadroxil, penicillin $\mathrm{G}$, vancomycin, iopromide, and fenbendazole) (Fig. 1) because of their high sensitivity and ability to provide compound confirmation, but only two or three compounds of these pharmaceuticals were analyzed simultaneously and there are only a few reports or papers which analyzed and determined these six analytes simultaneously. ${ }^{11-13}$

This paper details a sensitive and reliable analytical method for the determination of these six pharmaceuticals in surface water by LC/MS/MS and the occurrences of pharmaceuticals from four rivers in South Korea are shown.

\section{Experimental}

\subsection{Equipment and chemicals}

HLB (200 mg, $6 \mathrm{cc}$ ) cartridges for solid phase extraction were purchased from Waters (Milford, Massachusetts, USA). Cefadroxil, penicillin G, cephradine, fenbendazole, and vancomycin were obtained from Sigma-Aldrich Co. (St Louis, MO, USA) and iopromide from USP; all pharmaceutical standards were of analytical grade and high purity ( $>90 \%$ ). The reference compound, amoxicillin- $6-{ }^{13} \mathrm{C}$, used as surrogate standards and internal standard, was purchased from Cambridge Isotope Laboratories Co. (Andover, MA, USA). Methanol, acenonitrile, and water were of HPLC grade (J.T. Baker Co., NJ, USA). $\mathrm{Na}_{2}$-EDTA (Junsei Co., Tokyo, Japan), hydrochloric acid (Wako Co., Osaka, Japan), ammonium acetate (Merck Co., Darmastadt, Germany), formic acid 
(Fluka Co., Seelze, Germany) and ammonium hydroxide (Samchun Co., Gyeonggi-do, Korea) were obtained from commercial sources and typically were at purity of $90 \%$ or greater.

All stock solutions of standards and surrogates were prepared in methanol or distilled water to $1000 \mu \mathrm{g} / \mathrm{mL}$ and stored at $-20{ }^{\circ} \mathrm{C}$ in the dark. Mixed working solutions $(10 \mu \mathrm{g} / \mathrm{mL})$ were prepared fresh daily by diluting the individual stock solution with the same solvent and stored at $4{ }^{\circ} \mathrm{C}$.

\subsection{Sample preparation}

Before analysis of LC/ESI-MS/MS, samples were cleaned and extracted for removal of a matrix interfering in analysis and concentration of the analytes.

$250 \mathrm{~mL}$ of an aqueous sample was added to $1 \mathrm{~mL}$ of $5 \% \mathrm{Na}_{2}$.EDTA and $25 \mu \mathrm{L}$ of amoxicillin- $6-{ }^{13} \mathrm{C}$ (internal standard) and adjusted to $\mathrm{pH} 2$ with $0.5 \mathrm{M}$ $\mathrm{HCl}$. The Oasis HLB (200 mg, $6 \mathrm{cc}$ ) was preconditioned sequentially with $3 \mathrm{~mL}$ of methanol, $3 \mathrm{~mL}$ of $0.5 \mathrm{M} \mathrm{HCl}$ (in water), and $3 \mathrm{~mL}$ of purified water. Samples were loaded through the preconditioned

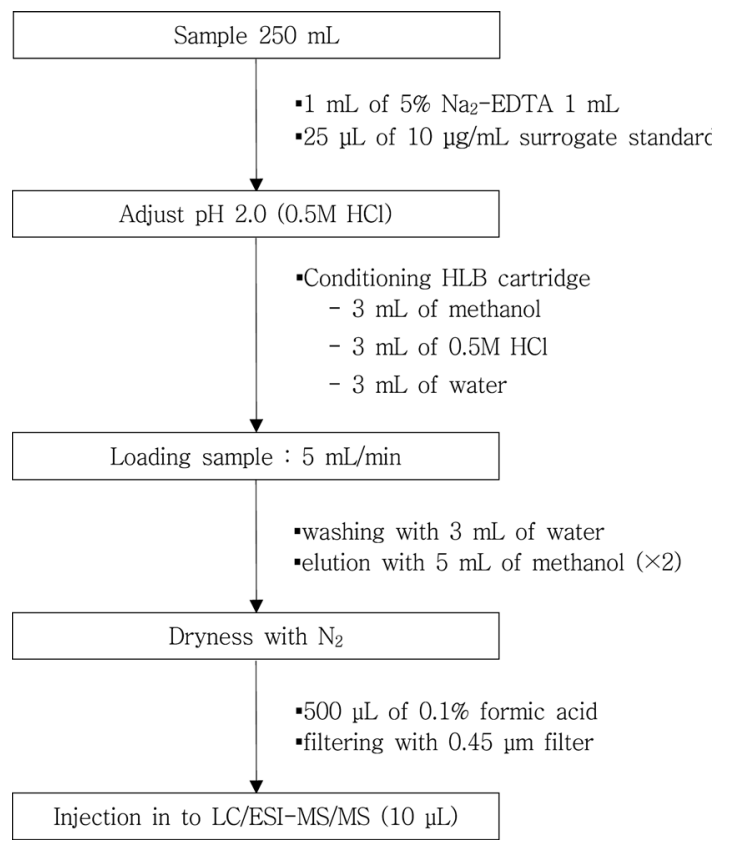

Fig. 2. Schematic diagram for six pharmaceuticals from surface water.
HLB cartridge at $5 \mathrm{~mL} / \mathrm{min}$. A sample that passed through the completely was washed with $3 \mathrm{~mL}$ of purified water, and pharmaceuticals were eluted with $5 \mathrm{~mL}$ of methanol. The eluant was evaporated until dry with a nitrogen evaporative concentrator. Residues were reconstituted with $500 \mu \mathrm{L}$ of $0.1 \%$ formic acid. The reconstituted sample was filtered through a $0.45 \mu \mathrm{m}$ syringe filter, transferred to a $2 \mathrm{~mL}$ vial, and analyzed by LC/ESI-MS/MS (Fig. 2).

\subsection{Instrumental Analysis}

The solution obtained from sample preparation was analyzed according to instrumental conditions which are shown in Table 1.

Separation of pharmaceuticals was performed on a reverse phase CAPCELL PAK C18 column ( $4.6 \mathrm{~mm}$ I.D., $100 \mathrm{~mm}$ length, 3 particle size). Mobile phase A ( $0.1 \%$ formic acid) and phase B (acetonitrile) were used with a flow rate of $0.5 \mathrm{~mL} / \mathrm{min}$. The separation was achieved with the following linear gradient system: at 0 min $A: B=95: 5(v / v), 5 \min A: B=50: 50$, $11 \min \mathrm{A}: \mathrm{B}=20: 80$, and $15.01 \mathrm{~min} \mathrm{~A}: \mathrm{B}=95: 5$. $\mathrm{A}$ $10 \mathrm{~min}$ post-time allowed re-equilibration of the column. Injection volume was $10 \mu \mathrm{L}$.

The instrumental analysis was performed on an Agilent 1200 series HPLC (Agilent Technologies, Palo Alto, CA, USA) equipped with a sample auto injector (Agilent 1200 series Autosampler) and utilized

Table 1. Instrumental conditions for the determination of the pharmaceuticals

\begin{tabular}{|c|c|}
\hline Parameters & Conditions \\
\hline Column & $\begin{array}{l}\text { CAPCELL PAK } \mathrm{C}_{18}, 4.6 \mathrm{~mm} \text { I.D., } \\
100 \mathrm{~mm} \text { length, } 3 \mu \mathrm{m} \text { particle size }\end{array}$ \\
\hline Mobile phase & $\begin{array}{l}\text { A : } 0.1 \% \text { Formic acid } \\
\text { B : Acetonitrile }\end{array}$ \\
\hline Gradient & $\begin{array}{llllllll}\text { Time }(\min ) & 0 & 5 & 8 & 11 & 15 & 15.01 & 25 \\
\text { Solvent } \mathrm{B}(\%) & 5 & 50 & 50 & 80 & 80 & 5 & 5\end{array}$ \\
\hline Column flow rate & $0.5 \mathrm{~mL} / \mathrm{min}$ \\
\hline Injection volume & $10 \mathrm{~mL}$ \\
\hline Column temperature & $25^{\circ} \mathrm{C}$ \\
\hline Ionization mode & Positive ion electrospray \\
\hline Gas temperature & $350{ }^{\circ} \mathrm{C}$ \\
\hline Capillary voltage & $3.50 \mathrm{kV}$ \\
\hline Gas flow & $10.0 \mathrm{~L} / \mathrm{min}\left(\mathrm{N}_{2}\right)$ \\
\hline Nebulizer & $45.0 \mathrm{psi}$ \\
\hline
\end{tabular}


the Agilent 6410 Triple Quadrupole tandem mass spectrometer (Agilent Technologies Palo Alto, CA, USA) for the confirmation and quantification of each separated analyte. Nitrogen was used as a desolvation gas (gas flow $10 \mathrm{~L} / \mathrm{min}$ ). The temperature of the desolvation gas was $350{ }^{\circ} \mathrm{C}$ and the capillary voltage was set to $3.5 \mathrm{kV}$. The analyses were carried out in MRM (multiple reactions monitoring) mode.

\section{Results}

Because analytes were in the pKa range of 2 3, these compound were loaded on the HLB cartridge in a neutral form in an acidic condition $(\mathrm{pH} 2)$ for effective retention on the cartridge. ${ }^{14,15}$ The analytes could interact with hydrophobic sites of the HLB cartridge and could be retained on the solid phase cartridge following extraction by the polar solvent. ${ }^{16}$

\section{1. $\mathrm{LC} / \mathrm{MS} / \mathrm{MS}$}

As shown Fig. 3, vancomycin eluted within the first $5.6 \mathrm{~min}$, and fenbendazole eluted by $10.8 \mathrm{~min}$, so six pharmaceuticals were effectively separated by $11 \mathrm{~min}$.

When analyzing compounds containing an acidic group in the chemical structure by LC/MS/MS in the positive ESI mode, formic acid has often been added to the mobile phase both to improve peak shape and to force production of $[\mathrm{M}+\mathrm{H}]^{+}$ions. Under acidic conditions, $[\mathrm{M}+\mathrm{H}]^{+}$species were observed mainly as the base peak in the full mass spectrum. The multiple reaction monitoring (MRM) parameters used (precursor ion and product ions) collision energies are listed in Table 2. Calibration curves for quantitation were

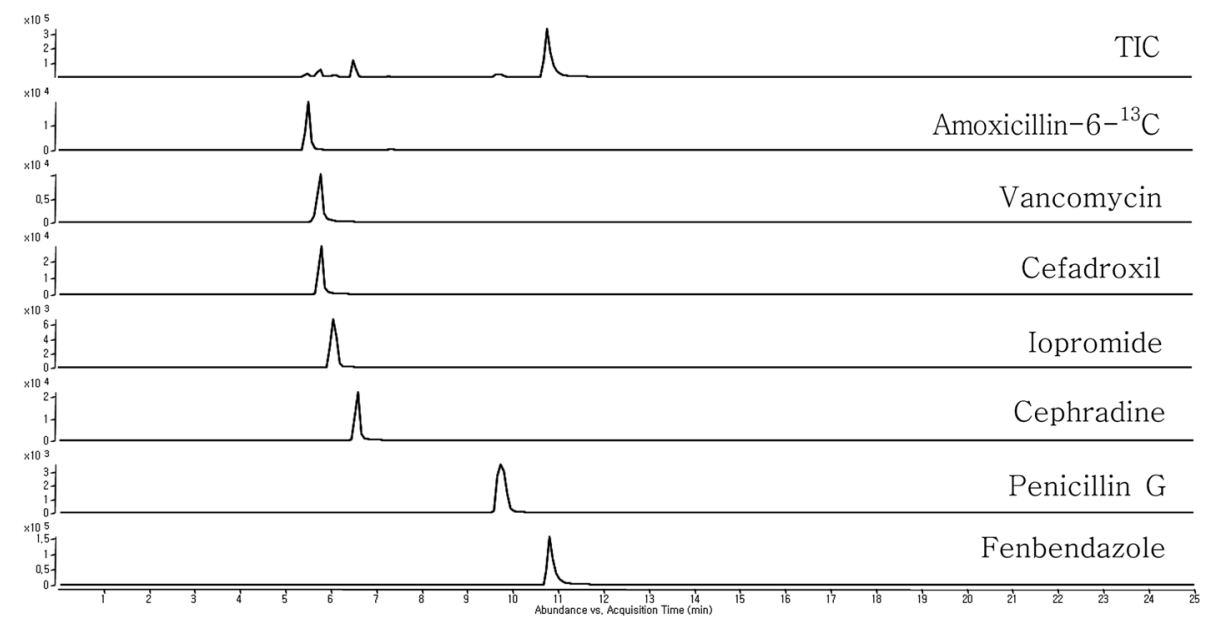

Fig. 3. Typical LC/MS/MS TIC (total ion chromatogram) and EICs (extracted ion chromatogram) of six pharmaceuticals from the spiked surface water samples.

Table 2. Retention time, precursor ion, characteristic ion and collision energy for the analysis of six pharmaceuticals and ISTD

\begin{tabular}{lcccccc}
\hline \hline \multicolumn{1}{c}{ Pharmaceuticals } & $\begin{array}{c}\text { R.T. } \\
(\mathrm{min})\end{array}$ & $\begin{array}{c}\text { Precursor } \\
\text { ion }(\mathrm{m} / \mathrm{z})\end{array}$ & Confirm ion (m/z) & $\begin{array}{c}\text { Quantitation } \\
\text { ion }(\mathrm{m} / \mathrm{z})\end{array}$ & $\begin{array}{c}\text { Collision } \\
\text { energy }(\mathrm{eV})\end{array}$ \\
\hline Vancomycin & 5.7 & 725 & 83 & 100 & 144 & 15 \\
Cefadroxil & 5.8 & 364 & 158 & 208 & 114 & 10 \\
Iopromide & 6.0 & 792 & 774 & 573 & 559 & 23 \\
Cefradine & 5.6 & 350 & 140 & 176 & 202 & 70 \\
Penicillin G & 9.7 & 335 & 91 & 190 & 268 & 25 \\
Fenbendazole & 10.8 & 300 & 159 & 214 & 114 & 25 \\
Amoxicillin-6- ${ }^{13} \mathrm{C}$ (ISTD) & 5.5 & 372 & 160 & & 5 \\
\hline
\end{tabular}


made with a quantitation ion provided from the precursor ion. Confirmation ions were used for qualitative confirmation of each compound.

\subsection{Calibration curves}

Calibration curves were constructed for analyte extracts from the spiked blank surface water at a concentration range of $0.0071 \sim 1.2 \mathrm{ng} / \mathrm{mL}$. The calibration curves were obtained from the peak area ratio of each pharmaceutical to the internal standard (amoxicillin-6- ${ }^{13} \mathrm{C}$ ) versus concentration in the surface water, and they were linear with the correlation of coefficients $\left(\mathrm{R}^{2}>0.99\right)$ (Table 3$)$.

\subsection{LOD, LOQ, recovery and accuracy}

The absolute recoveries (extraction yield) of six pharmaceuticals were measured by extracting analytes from spiked surface water at a concentration range of $0.0075 \sim 1.0 \mathrm{ng} / \mathrm{mL}$. The absolute recoveries were calculated by comparing the amounts of the compounds present in the final solution after running through the whole method (described in the "sample preparation"

Table 3. Linear equation and coefficient of correlation for the quantitation of six pharmaceuticals

\begin{tabular}{lccc}
\hline \hline Pharmaceuticals & Concentration $(\mathrm{ng} / \mathrm{mL})$ & Linear equation & Coefficient of correlation $\left(\mathrm{r}^{2}\right)$ \\
\hline Vancomycin & $0.0785 \sim 1.2$ & $\mathrm{y}=6.8241 \mathrm{x}-0.2955$ & 0.9952 \\
Cefadroxil & $0.0072 \sim 1.0$ & $\mathrm{y}=1.7934 \mathrm{x}+0.0854$ & 0.9960 \\
Iopromide & $0.028 \sim 1.0$ & $\mathrm{y}=2.7025 \mathrm{x}-0.0174$ & 0.9976 \\
Cefradine & $0.0071 \sim 1.0$ & $\mathrm{y}=1.5139+0.0989$ & 0.9937 \\
Penicillin G & $0.0813 \sim 1.0$ & $\mathrm{y}=1.4937 \mathrm{x}-0.0316$ & 0.9933 \\
Fenbendazole & $0.0102 \sim 1.0$ & $\mathrm{y}=3.39559+0.0190$ & 0.9969 \\
\hline
\end{tabular}

Table 4. Absolute recovery, limit of detection (LOD), limit of quantitation (LOQ), and precision, and accuracy (as bias)

\begin{tabular}{|c|c|c|c|c|c|c|}
\hline Pharmaceuticals & $\begin{array}{l}\text { LOD* } \\
(\mathrm{pg} / \mathrm{mL})\end{array}$ & $\begin{array}{l}\mathrm{LOQ}^{* *} \\
(\mathrm{pg} / \mathrm{mL})\end{array}$ & $\begin{array}{c}\text { Concentration } \\
(\mathrm{ng} / \mathrm{mL})\end{array}$ & $\begin{array}{c}\text { Recovery } \\
(\%)\end{array}$ & $\begin{array}{c}\operatorname{RSD}(\%)^{* * *} \\
(\mathrm{n}=3)\end{array}$ & $\begin{array}{c}\text { Bias**** } \\
(\%)\end{array}$ \\
\hline \multirow{3}{*}{ Vancomycin } & \multirow{3}{*}{122.7} & \multirow{3}{*}{409.0} & 0.25 & 89.5 & 6.6 & 17.4 \\
\hline & & & 0.4 & 79.2 & 5.2 & 1.1 \\
\hline & & & 1.2 & 81.5 & 6.1 & -1.5 \\
\hline \multirow{3}{*}{ Cefadroxil } & \multirow{3}{*}{10.4} & \multirow{3}{*}{34.7} & 0.02 & 82.6 & 7.7 & 13.1 \\
\hline & & & 0.2 & 87.8 & 5.3 & -8.0 \\
\hline & & & 1.0 & 88.1 & 5.0 & -1.8 \\
\hline \multirow{3}{*}{ Iopromide } & \multirow{3}{*}{44.7} & \multirow{3}{*}{149.1} & 0.075 & 92.6 & 3.2 & 11.5 \\
\hline & & & 0.2 & 85.5 & 2.1 & -10.5 \\
\hline & & & 1.0 & 90.9 & 2.5 & -0.4 \\
\hline \multirow{3}{*}{ Cefradine } & \multirow{3}{*}{7.2} & \multirow{3}{*}{23.8} & 0.1 & 85.6 & 7.0 & -4.6 \\
\hline & & & 0.2 & 84.3 & 5.2 & 1.0 \\
\hline & & & 1.0 & 82.2 & 8.6 & -1.2 \\
\hline \multirow{3}{*}{ Penicillin G } & \multirow{3}{*}{128.7} & \multirow{3}{*}{429.1} & 0.25 & 71.1 & 11.2 & 12.8 \\
\hline & & & 0.4 & 76.3 & 8.9 & -3.6 \\
\hline & & & 1.0 & 74.2 & 10.5 & -3.0 \\
\hline \multirow{3}{*}{ Fenbendazole } & \multirow{3}{*}{10.3} & \multirow{3}{*}{34.2} & 0.025 & 31.2 & 8.5 & 7.3 \\
\hline & & & 0.6 & 33.2 & 7.7 & 1.3 \\
\hline & & & 1.0 & 30.3 & 8.9 & -4.0 \\
\hline
\end{tabular}

*LOD : Limits of Detection $(3 \mathrm{~s} / \mathrm{m})$

**LOQ : Limits of Quantification $(10 \mathrm{~s} / \mathrm{m})$

$* * * \mathrm{RSD}=\mathrm{s}$ /average $\times 100$

$* * * * \operatorname{Bias}=($ calculated value-measured value $) /$ calculated value $\times 100$ 
section) with spiked surface water with the amounts that were injected without the sample preparation procedure. Three replicates of absolute recovery samples were analyzed. Recoveries ranged between 71.1 to $92.6 \%$ (except fenbendazole) and the overall variability of the method was below $11.2 \%$ (RSD) (Table 4). The high extraction efficiency may be due to the strong interactions between the analytes and the retention sorbent, resulting in the excellent performance of the HLB cartridges for the extraction of the six pharmaceuticals. It is likely that lower recovery of fenbendazole (30 33\%) was due to the different physical property (pKa) mainly. Although fenbendazole exhibited a lower absolute recovery, the mass spectrometric sensitivity for fenbendazole was higher than that of other compounds and the precision was good.

The limit of detection (LOD) was defined as $3 \mathrm{~s} /$ $\mathrm{m}$, where $\mathrm{s}=$ standard deviation and $\mathrm{m}=$ slope of calibration curve. The LOD for the analytes was in the range of $7.2 \sim 128.7 \mathrm{pg} / \mathrm{mL}$, and the limits of quantitation (LOQ), which was defined as $10 \mathrm{~s} / \mathrm{m}$, was in the range of $23.8 \sim 429.1 \mathrm{pg} / \mathrm{mL}$ in the spiked surface water. Cefradine exhibited the lowest LOD and LOQ, and penicillin G had the highest of the six pharmaceuticals. The results are summarized in Table 4.

The accuracies (as bias) range in the surface water were $-10.5 \sim 17.4 \%$. The results were well within the recommended acceptable values of $-30 \%$ to $+20 \%$ at each concentration level. ${ }^{17}$ The precisions (as the relative standard deviation (RSD)) of the three replicates at the three concentration levels in the spiked surface water sample were in the range of $2.1 \sim 11.2 \%$.

\subsection{Occurrences of pharmaceuticals in surface water}

The established analytical method was successfully applied to monitor the occurrence of pharmaceuticals in surface water. The samples were collected from 40 sites from four main river (Han River, Geum River, Youngsan River, and Nakdong River) in South Korean from June, 2009 to November, 2009. Iopromide was detected at a higher frequency of detection of $77 \%$ and a concentration range of $0.036 \sim 6.488 \mathrm{ng} / \mathrm{mL}$. The fenbendazole was found at a frequency of detection of $5 \%$ and a concentration range of $0.005 \sim 0.04 \mathrm{ng} / \mathrm{mL}$. The other pharmaceuticals were not detected.

\section{Conclusion}

A sensitive, reliable, and reproducible simultaneous analytical method has allowed the detection of six pharmaceuticals in surface water. This established analytical method showed good absolute recovery in the $71.1 \sim 92.6 \%$ range, and a comparatively sensitive limit of detection range of $7.2 \sim 128.7 \mathrm{pg} / \mathrm{mL}$, and a limit of quantitation of $23.8 \sim 429.1 \mathrm{pg} / \mathrm{mL}$. In a few samples of surface water, iopromide and fenbendazole were detected in high concentrations.

\section{Acknowledgments}

This work was financially supported by the National Institute of Environmental Research.

\section{References}

1. D. Fatta, A. Nikolaou, A. Achilleos and S. Meric, Trends Anal. Chem., 26(6), 515-533(2007).

2. M. Carballa, F. Omil, T. Ternes and J. Lema, Water Research, 41(10), 2139-2150(2007).

3. P. Westehoff, Y. Yoon, S. Snyder and E. Wert, Environ. Sci., 39(17), 6649-6663(2005).

4. C. Zwiener and F. H. Frimmel, Anal Bioanal Chem., 378(4), 862-874(2004).

5. S. Mompelat, B. Le Bot and O. Thomas, Environment International, 35(5), 803-814(2009).

6. A. Yu-Chen Lin, Y. Tsung-Hsein and L. Cheng-Fang, Chemosphere 74(1), 131-141(2008).

7. J. C. Vand De Steene, K. A. Mortier and W. E. Lambert, J. Chromatogr. A., 1123(1), 71-81(2006).

8. A. R. Fernández-Alba and J. F. García-Reyes, Trends Anal. Chem., 27(11), 973-990(2008).

9. M. S. Díaz-Cruz and D. Barceló, D. Trends Anal. Chem. 26(6), 637-646(2007).

10. J. Radjenovic, M. Petrovic and D. Barceló, Trends 
Anal. Chem., 28(5), 562-580(2009).

11. F. Busetti, K. L. Linge, J. W. Blythe and A. Heitz, J. Chromatogr. A., 1213(12), 200-208(2008).

12. W. Seitz, W. H. Weber, J. Jia-Qian, B. J. Lloyd, M. Maier, D. Maier and W. Schulz, Chemosphere, 64(8), 1318-1324(2006).

13. M. Petrovic and D. Barceló, Trends Anal. Chem., 26(6), 486-493(2007).

14. S. Pérez and D. Barceló, Trends Anal. Chem., 26(6),
494-514(2007).

15. A. Joss, S. Zabczynski, A. Göbel, B. Hoffmann, D. Löffler, C. S. McArdell, T. A. Ternes and H. Siegrist, Water Research, 40(8), 1686-1696(2006).

16. T. Kosjek and E. Heath, Trends Anal. Chem., 27(10), 807-820(2008).

17. M. Cherlet, S. D. Baere, S. Croubels and P. D. Baker, Anal. Chim. Acta., 1000(1-2), 503-526(2003). 